\title{
ASSESSING THE LANDSCAPE PATTERN AND POPULATION STATUS OF THE TIMBER SPECIES MANSONIA ALTISSIMA A. CHEV. FOR RESTORATION PURPOSES IN MOIST SEMI-DECIDUOUS FOREST.
}

\author{
ADIGLA APPOLINAIRE WÉDJANGNON ${ }^{1} * *$, YVON-CARMEN H. HOUNTONDJI ${ }^{1}$, \\ CHRISTINE A. I. NOUGBODÉ OUINSAVI ${ }^{1}$
}

\author{
${ }^{1}$ Laboratoire d'Etudes et de Recherches Forestières (LERF), Faculté d'Agronomie, \\ Université de Parakou, O3BP 123 Parakou, Benin \\ *Corresponding author:wedjangnon_app@yahoo.com
}

Received: $22^{\text {th }}$ December 2019, Accepted: $8^{\text {th }}$ June 2020

\begin{abstract}
Mansonia altissima A. Chev., a redwood producer species in tropical Africa, occurs as one small, isolated population in a highly anthropized landscape in Republic of Benin. We accessed the landscape pattern and population status to inform restauration action for the species. We established 20 one-ha permanent plots divided in 320 subplots $(25 \mathrm{~m} \times 25 \mathrm{~m})$ in-situ and counted and measured M. altissima plants with diameter $\geq 1 \mathrm{~cm}$ at base and $1.30 \mathrm{~m}$ above ground (DBH) in February 2017, 2018 and 2019. Based on the main disturbance factors, such as fire, human-caused damage to seedlings, harvesting of wood for fuel, and agriculture, we assigned the plots to one of three disturbance levels: poor, moderate, and strong. We grouped the plants into four life stages according to diameter size $(\mathrm{cm})$ : seedling $(1 \leq \mathrm{DBH}<5)$, sapling $(5 \leq \mathrm{DBH}<10)$, premature $(10 \leq \mathrm{DBH}<20)$, and mature $(\mathrm{DBH} \geq 20)$. We used Landsat data of years 1986, 2002 and 2017 to quantify and analyze landscape changes and fragmentation. Results showed that the landscape was dramatically changed and fragmented between 2002 and 2017 due to disturbance increase. Semi-deciduous forest (SDF) containing M. altissima decreased, whereas woodlands and savannas increased. SDF was severely fragmented and disaggregated. In plots with strong disturbance, mortality rate was higher, whereas in plots with poor disturbance, it was lower and recruitment was highest. Mortality rate differed significantly among life stages and disturbance levels. Experimental restoration is required to identify locations where the species can establish young viable populations. Fire and other anthropogenic disturbance have to be controlled to ensure this natural population can provide seeds for restoration and conservation projects.
\end{abstract}

Keywords: remote sensing; landscape fragmentation; conservation; restoration; threatened species; Mansonia altissima

\section{INTRODUCTION}

Moist forests are very important for conservation of forest resources, regulation of biogeochemical cycles and carbon storage. Accelerated disappearance of these specific habitats, puts them on to the forefront of environmental concerns. Many plant species are 
facing the risk of extinction due to habitat fragmentation, degradation and destruction (Tang et al., 2011). Fragmentation may have severe consequences as loss of viable habitat for shade-tolerant plant species, genetic diversity reduction and local extinctions of native species (Laurance et al., 2009; Mendoza et al., 2005). Anthropogenic disturbance levels and landscape changes are recognized like drivers of strong modifications in plant population structure and demographic rates (Mensah et al., 2014; Selwood et al., 2014). Demographic responses of species facing landscape changes due to anthropogenic disturbance give more proximal indication of how anthropogenic disturbance affect population viability and contribute to extinction risk (Selwood et al., 2014). Theoretically and empirically, the extinction risk is higher in smaller populations (Volis \& Deng, 2019; Ellstrand \& Elam, 1993). Likely, land-use changes in forest habitats often result in changes in plant population size, a decrease in regeneration density and disturbance in pollination services due to changes in specific ecology of pollinators (Klank et al., 2010). Tree regeneration includes seedlings establishment and growth (Klopčič et al., 2015). Both seedlings and saplings abundance commonly decreases with their age and can be explained by some factors as the reduced availability of resources, increase competition by herbaceous layer or intra and interspecific competition, and exogenous mortality factors (Klopčič et al., 2015). Knowledge of the risks faced by small populations and the processes that lead to a decrease in their abundance and viability threshold allows conservation practitioners to intervene to avoid extinction and maintain population viability. Therefore, an assessment of the demographic structure and factors that affect demography and viability of small populations in changing habitats is a priority for conservation biology (Volis, 2018; Volis \& Deng, 2019).

Evaluation and monitoring of the established forest habitats are essential priorities for habitat restoration because they allow to inform success or failure of interventions and help to correct restoration trajectory through adaptive management (Reis et al., 2019). Remote sensing plays an important role in this way by quantifying ecosystem degradation, conservation (Cabello et al., 2012) and restoration (Cordell et al., 2018; Questad et al., 2014). Indeed, satellite imagery is used in conservation biology for classifying and describing vegetation patterns and habitats of species (Pereira \& Cooper, 2006). In addition, conservation of critically endangered species requires accurate data to support decisions at landscape scales (Questad et al., 2014). Remote sensing provides useful data for land-use, land-cover mapping from Landsat satellite imagery (Ashton et al., 2018). The supervised classification techniques of these high resolution images combined with an expert system are promising tools to monitor and assess suitable habitats for species conservation and restoration (Reis et al., 2019).

Mansonia altissima A. Chev., a tropical redwood species found in West-Central Africa, is recently listed as Least Concern (Botanic Gardens Conservation International and IUCN SSC Global Tree Specialist Group, 2018). Nevertheless, Mansonia altissima var. altissima A. Chev. is still listed as Endangered on the IUCN Red List, but this assessment was conducted more than 20 years ago (African Regional Workshop, 1998). A more recent assessment lists this species as Critically Endangered in Republic of Benin (Neuenschwander et al., 2011) because its wood has been actively used in construction (Wédjangnon et al., 2016) and its habitat is degrading. Information on suitability of this habitat for the conservation of the species are practically non-existent.

To establish a baseline of interventions for the conservation of this species, we studied changes inside its habitat and its population status. We expressed the hypothesis that anthropogenic disturbance has driven landscape changes which negatively affected the population status of the timber species $M$. altissima. We used landscape ecology and population dynamics approaches to inform conservation and restoration action for 
M. altissima. We used demographic variable sets such as recruitment, mortality, and diameter increment rates (Ashton et al., 2018; Tang et al., 2011) to assess the population status of $M$. altissima in Benin and compared mortality and recruitment by degree of habitat disturbance and life stage. The following questions were addressed: What is spatial and temporal evolution of landscape categories in the natural habitat of M. altissima? What are the ecological factors of forest cover decline in the natural habitat of the species? To what extend degradation of this natural habitat affect the demography of the species?

\section{MATERIALS AND MeTHODS}

\section{Study area}

Native distribution range of the natural population of $M$. altissima in Republic of Benin is a moist semi-deciduous forest $\left(7^{\circ} 27^{\prime}-7^{\circ} 29^{\prime}\right.$ North, $2^{\circ} 33^{\prime}-2^{\circ} 35^{\prime}$ East) in the District of Adakplamè in municipality of Kétou (Figure 1). This habitat is contiguous to residential and agricultural spaces. The forest covers about 738 ha, which is partly occupied by houses. The climate of study area is subequatorial with annual bimodal rainfall of about 1,300 mm. The rainy season starts in March and end in November with rain deficit between July and September.

Fig. 1: Location of the sacred grove of Adakplamè

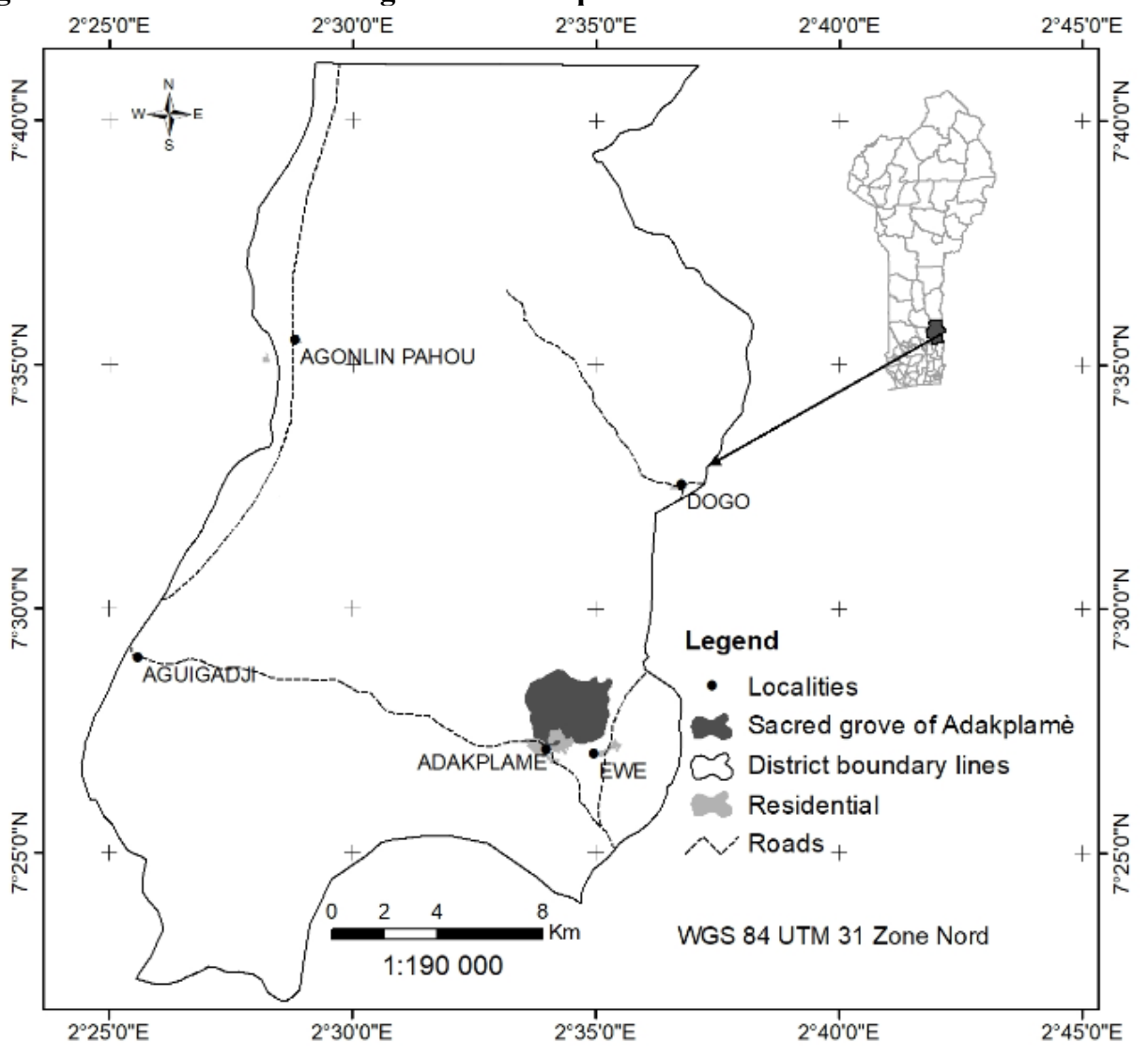


The dry season ranges from November to March. The average annual temperature is $26.5^{\circ} \mathrm{C}$ and average annual relative humidity is about $75 \%$ year $^{-1}$. The studied habitat is considered as sacred grove since colonial period (before 1960) because some deities were lodged inside since 1600 (PIFSAP, 2012). In order to protect the abode of deities, this habitat was protected by traditional authorities and became a refuge for some rare species from tropical semi-deciduous forests. However, weakness of traditional authorities due to emergence of monotheistic or extraneous religions led overlaps of the habitat which affected plant population viability (A. Wédjangnon). The breakdown of social taboos has led to logging, fire, and other human disturbance in the forest. One of the most threatened species is Mansonia altissima var. altissima A. Chev., whose population had been overexploited for house building (Wédjangnon et al., 2016) because its wood is valuable.

\section{Data collection}

\section{Monitoring of forest cover changes}

We downloaded three satellite images from sensors Landsat TM (Thematic Mapper), ETM + (Enhanced Thematic Mapper Plus) and OLI (Operational Land Imager) from the web site https://earthexplorer.usgs.gov/. These images of footprint Path/Row 192/55 were respectively acquired on 01/13/1986, 01/17/2002 and 02/19/2017.

We carried out digital image pre-processing (radiometric and atmospheric corrections) with ENVI 5.1. We used Fast Line-of-sight Atmospheric Analysis of Hypercubes (FLAASH) algorithm to correct wavelengths in the visible through NIR (near-infrared) and the shortwave infrared (SWIR) up to $3 \mu \mathrm{m}$. We created a subset of each pre-processed image using polygon shapefile of the forest and computed Normalized Difference Vegetation Index (NDVI). We used NDVI band created to discriminate forest and non-forest cover types on the landscape (Reis et al., 2019; Buma, 2011). We used supervised classification technique with Maximum Likelihood algorithm to categorize forest/non-forest classes based on our knowledge from the forest and information provided in the forest management program (PIFSAP, 2012). We assigned pixels from each subset image to the landscape categories with a probability threshold $70 \%$. We carried out spectral separability analysis of landscape categories using Jeffries-Matusita, Transformed Divergence's index and combined similar categories with index value lower than 1 . We validated pre-defined landscape categories with 185 control points sampled from the three pre-processed images. We recorded geographical coordinates of points and found them in the forest using global positioning system (GPS). We carried out field controls during both rainy (August 2017) and dry (February 2018) seasons. We used the software ArcGIS 9.3.1 for GIS applications.

\section{Sampling design and demographic data collection}

We established 20 one-ha permanent plots containing $M$. altissima within the Adakplamè District forest and further divided each plot into 16 subplots $(25 \mathrm{~m} \times 25 \mathrm{~m})$. We recorded $M$. altissima trees with diameter $\geq 1 \mathrm{~cm}$. We marked plants with diameter at breast height $(\mathrm{DBH}) \geq 5 \mathrm{~cm}$ using stencil painting and tagged plants with collar diameter between $1 \mathrm{~cm}$ and $5 \mathrm{~cm}$. We carried out censuses and measurements in dry season, each and only in the month of February 2017, 2018 and 2019. We counted all plants of M. altissima within subplots and measured them using an electronic Vernier caliper (Kreator Stainless Hardened) for juveniles and a pi tape for adult trees. We also marked all plants recruited between February 2017 and 2019. We assessed recruitment for only two life stages: seedling ( $1 \geq$ $\mathrm{DBH}<5 \mathrm{~cm})$ and sapling $(5 \geq \mathrm{DBH}<10 \mathrm{~cm})$. We considered seedlings like plant establishment stage, and saplings like plant emergence stage. As field data collection term 
Wédjangnon et.al: Assessing the landscape pattern and population status of the timber species Mansonia altissima A. Chev. for restoration purposes in moist semi-deciduous forest.

coincided with the fruit ripening period of M. altissima, we recorded all trees having fruited at least once during the three censuses.

We also used GPS to record geographical coordinates of trees in order to find and identify them during successive censuses. We also recorded trees on plot edges and eliminated creepers on the stem. All trees marked at the first census were alive. We supplemented DBH measurements with indications of conditions under which the measurement was carried out, such as the stem's shape at the location of the painting line and some global peculiarities of trees. To measure population factors, we used codes such as NORM: no particular abnormality of the stem, INCL: tree inclined, making an angle of at least $20^{\circ}$ with the observer, REJ: tree stump reject, MORI: dying tree, CHAB1: tree fallen or broken due to strong winds, CHAB2: fall caused by another tree. We measured anthropogenic disturbance factors within each plot using codes, such as FEU: tree hit by fire, BLE: tree injured or peeled by people, BRUL: totally burnt tree, MORT: dead tree standing, EXPL: tree logged by people, TUE: tree killed to extend agricultural area.

\section{Data analysis}

\section{Landscape change and fragmentation analysis}

To quantify changes among the landscape categories we used the transition matrix from the three different periods, 1986, 2002 and 2017. We determined the gain intensity and loss intensity for each category using Pontius' intensity analysis program "IntensityAnalysis03 .xlms" (Aldwaik \& Pontius, 2012). We determined the rate of land cover change using the algebraic model (1) (Puyravaud, 2003). It given the percentage of change in each category annually.

$$
R=100 /\left(t_{2}-t_{1}\right) \ln \left(A_{2} / A_{1}\right)
$$

$\mathrm{R}$ : rate of land cover change per year; A1, A2: surface of the category at the period t1 (1986) and t2 (2017); ln: natural logarithm. We assessed the landscape pattern from class metrics computed with FRAGSTATS v4.2 (McGarigal et al., 2012) for each classified image individually using eight landscape pattern indices (Table 1).

\section{Table 1: Metrics computed to assess landscape pattern in the sacred groves of} Adakplamè

\begin{tabular}{|c|c|c|}
\hline Metrics & Description & Units \\
\hline NP & $\begin{array}{l}\text { Number of patches of the category of the corresponding landscape. We computed it with } \\
\text { 8-neighbor rule for delineating patches. }\end{array}$ & None \\
\hline LPI & Largest Patch Index is the percentage of landscape area comprised by the largest patch & $\%$ \\
\hline nLSI & $\begin{array}{l}\text { Normalized Landscape Shape Index, is ranged from } 0 \text { to } 1 \text {. When the landscape consists of a } \\
\text { single square nLSI }=0 \text { and becomes increasing when the category becomes increasingly } \\
\text { disaggregated }\end{array}$ & None \\
\hline MPS & Mean Patch Size & ha \\
\hline $\mathrm{CV}$ & Patch size coefficient of variation, measures relative variability of patch size about the mean. & None \\
\hline PAFRA & Perimeter-Area Fractal Dimension, measures patch shape irregularity and is ranged from 1 to 2 . & None \\
\hline & $\begin{array}{l}\text { PAFRAC value greater than } 1 \text { indicates an increase in patch shape complexity. PAFRAC is } \\
\text { undefined as the number of patches is }<10\end{array}$ & \\
\hline AI & $\begin{array}{l}\text { Aggregation Index, measures frequency of patch adjacencies. Increase of AI value indicates an } \\
\text { increase aggregation }\end{array}$ & $\%$ \\
\hline ENN & $\begin{array}{l}\text { Euclidean Nearest-Neighbor Distance, is the distance from a patch to nearest neighboring patch } \\
\text { in the same category }\end{array}$ & $\mathrm{m}$ \\
\hline
\end{tabular}
Full 
Analysis of population demographic variables of M. altissima

Based on the main anthropogenic disturbance factors, such as fire, damage of human activities on seedlings, harvesting of wood for fuel, and agriculture extent, we assigned 1-ha plots to three disturbance levels: poor, if none of these main disturbance factors was noted (7 plots); moderate, if the main disturbance factor was damage of human activities on seedlings (4 plots); strong, if the main disturbance factors were fire and agriculture ( 9 plots). We grouped all plants censured into four life stages according to biological variables, such as minimum flowering and fruiting diameter (Ouédraogo et al., 2018) and annual growth rate (De Madron, 2003): seedling $(1 \leq \mathrm{DBH}<5)$, sapling $(5 \leq \mathrm{DBH}<10)$, premature $(10 \leq \mathrm{DBH}$ $<20)$, and mature $(\mathrm{DBH} \geq 20)$.

We estimated trees growth rates among the life stages from the diameter increment of trees using algebraic model (2) (Dionisio et al., 2018; Favrichon et al., 1998). We determined the diameter increment with plants have no particular abnormality and were living between the three successive censuses (Favrichon et al., 1998). We estimated the plant mortality and recruitment rates using algebraic models (3) and (4) (Dionisio et al., 2018; Gross et al., 2018).

$$
\begin{aligned}
& D_{\text {incr }}=\left(d_{t}-d_{0}\right) / T \\
& \widehat{m}=\left(1-\left[\left(N_{0}-\text { dead }\right) / N_{0}\right]^{\frac{1}{T}}\right) \times 100 \\
& \hat{r}=\left(1-\left[1-\left(\text { recr } / N_{t}\right)\right]^{\frac{1}{T}}\right) \times 100
\end{aligned}
$$

$D_{\text {incr }}$ : diameter increment $\left(\mathrm{cm} \mathrm{year}^{-1}\right) ; d_{0}$ : diameter at initial census; $d_{t}$ : diameter at last census; $T$ : time interval (yr) between initial and last census; $\widehat{m}$ : mortality rate $\left(\%\right.$ year $\left.^{-1}\right) ; N_{0}$ : number of living plants recorded at initial census; $N_{t}$ : number of surviving plants until last census; $\hat{r}$ : recruitment rate $\left(\%\right.$ year $\left.^{-1}\right)$; recr: number of plants both recruited and living until last census.

We used binary logistic regression analysis (family binomial, link probit) to test the link between mortality, disturbance level, and life stage. We performed same analysis for recruitment according to the disturbance levels. We analyzed differences in annual diameter increments in relation to the life stages and disturbance levels using the Kruskal-Wallis' test. We also analyzed the correlation among diameter increment and initial DBH using the Spearman's rank correlation test. We performed all analyses using the software R v3.4.4 (Core Team, 2018).

\section{RESULTS}

\section{Spatial and temporal evolution and change in forest extent}

We identified distinctly four forest/non-forest categories from forest landscape of which, three forest categories (semi-deciduous forests, woodlands, and savannas) and a non-forest category, which combined both agriculture and residential spaces. Spatio-temporal evolution curves (Figure 2) showed regressive trends in semi-deciduous forests (SDF), whereas woodlands and savannas showed progressive trends. The area from non-forest category remained quasi permanent (Figure 3). SDF and woodlands dominated the forest in 1986 with 243.7 ha and 297.0 ha respectively, but after three decades (1986 to 2017), SDF decreased dramatically with only 103 ha against 362.9 ha woodlands and 233.6 ha savannas. 
Fig. 2: Spatial and temporal evolution of landscape categories from 1986 to 2017

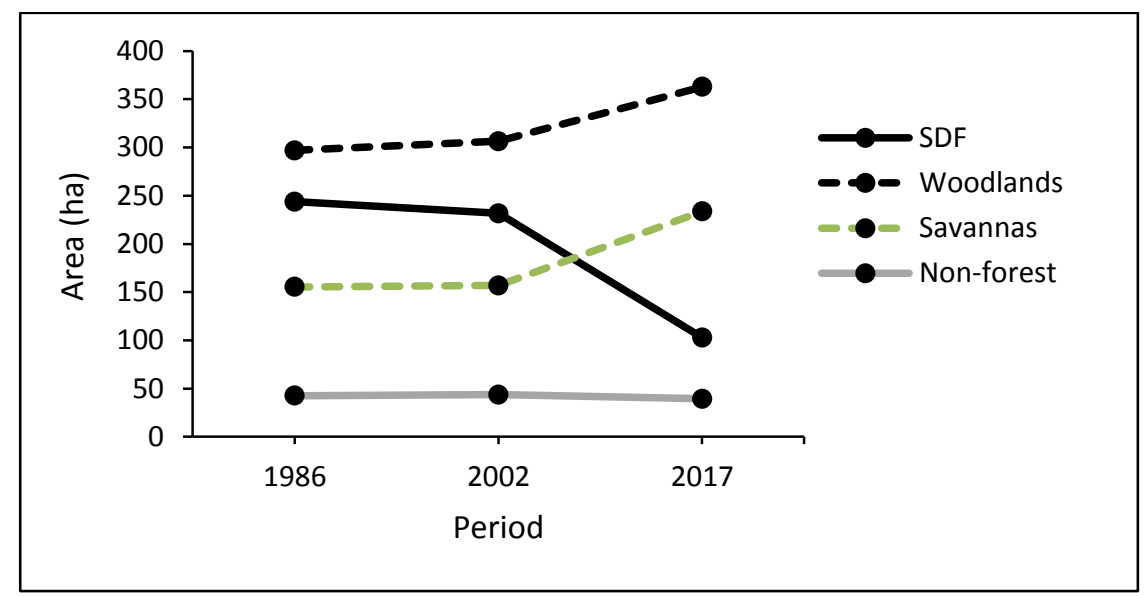

Table 2 shows inter-category transition matrix and rate of land cover change in landscape categories. In terms of gain, the inter-category transition matrix showed that among the four categories only woodlands replaced SDF when they gained during the period 1986 to 2002 (Figure 4). During this period, the quantity of change from SDF to woodlands $(7.3 \%$ of the total landscape area) and woodlands to SDF (5.3\% of the total landscape area) were lower and could be qualified like swap. However, dramatic changes occurred since 2002 with important loss in SDF estimated to $25.2 \%$ of the total landscape area in 2017. This important loss occurred mainly from SDF to woodlands $(23.4 \%)$ and savannas $(1.8 \%)$ suggested that expansion of woodlands was the major cause of SDF loss (Figure 4). Only $6.1 \%$ of the total landscape area remained in SDF. Non-forest category (agriculture and residential spaces) did not replace SDF during the period 1986 to 2017.

Table 2: Inter-category transition matrix and rate of change in the forest from 1986 to 2017

\begin{tabular}{clccccccc}
\hline Period & Land category & SDF & Woodlands & Savannas & Non-forest & Gain & Loss & R $\left(\%\right.$ year $\left.^{-1}\right)$ \\
\hline $1986-2002$ & SDF & 25.6 & 7.3 & 0 & 0 & 1.1 & 1.4 & -0.2 \\
& Woodlands & 5.3 & 29.1 & 5.5 & 0.3 & 1.9 & 1.7 & 0.1 \\
& Savannas & 0.5 & 5.1 & 12.3 & 3.3 & 2.6 & 2.6 & 0.03 \\
& Non-forest & 0 & 0 & 3.4 & 2.3 & 3.8 & 3.7 & 0.1 \\
$2002-2017$ & SDF & 6.1 & 23.4 & 1.8 & 0 & 3.7 & 5.4 & -2.6 \\
& Woodlands & 7 & 21 & 11.5 & 2 & 3.8 & 3.3 & 0.5 \\
& Savannas & 0.8 & 4.5 & 15 & 1 & 3.5 & 2.0 & 1.3 \\
& Non-forest & 0 & 0 & 3.3 & 2.3 & 3.7 & 4.0 & -0.3 \\
\hline
\end{tabular}

$\mathrm{SDF}=$ semi-deciduous forest; Values are expressed in percent (\%) of the entire landscape (738.8 ha)

The rate of land cover change showed that the forest cover in SDF decreased over the three decades (Table 2). During the period 1986 to 2002, alone SDF decreased $\left(\mathrm{R}=-0.2 \%\right.$ year $^{-1}$ ) in the entire landscape. The period of the largest decline in forest cover was 2002 to 2017 $\left(\mathrm{R}=-2.6 \%\right.$ year $\left.^{-1}\right)$. During this period, although change from SDF to woodlands was important, the forest cover changed mainly from forests to savannas $\left(R=-1.3 \%\right.$ year $\left.^{-1}\right)$. The loss intensity was highest in SDF during the period 2002 to 2017, whereas the gain intensity was highest in woodlands (Table 2). 
The gain intensity and the loss intensity were highest in non-forest category due to its small size (5.8\% of the total landscape area). Changes in SDF followed up on regressive dynamic, whereas changes in woodlands and savannas followed up on progressive dynamic (Figure 4).

Fig. 3: Spatial and temporal distribution of landscape categories in the sacred groves of Adakplamè. The black triangles are sampling points of $M$. altissima
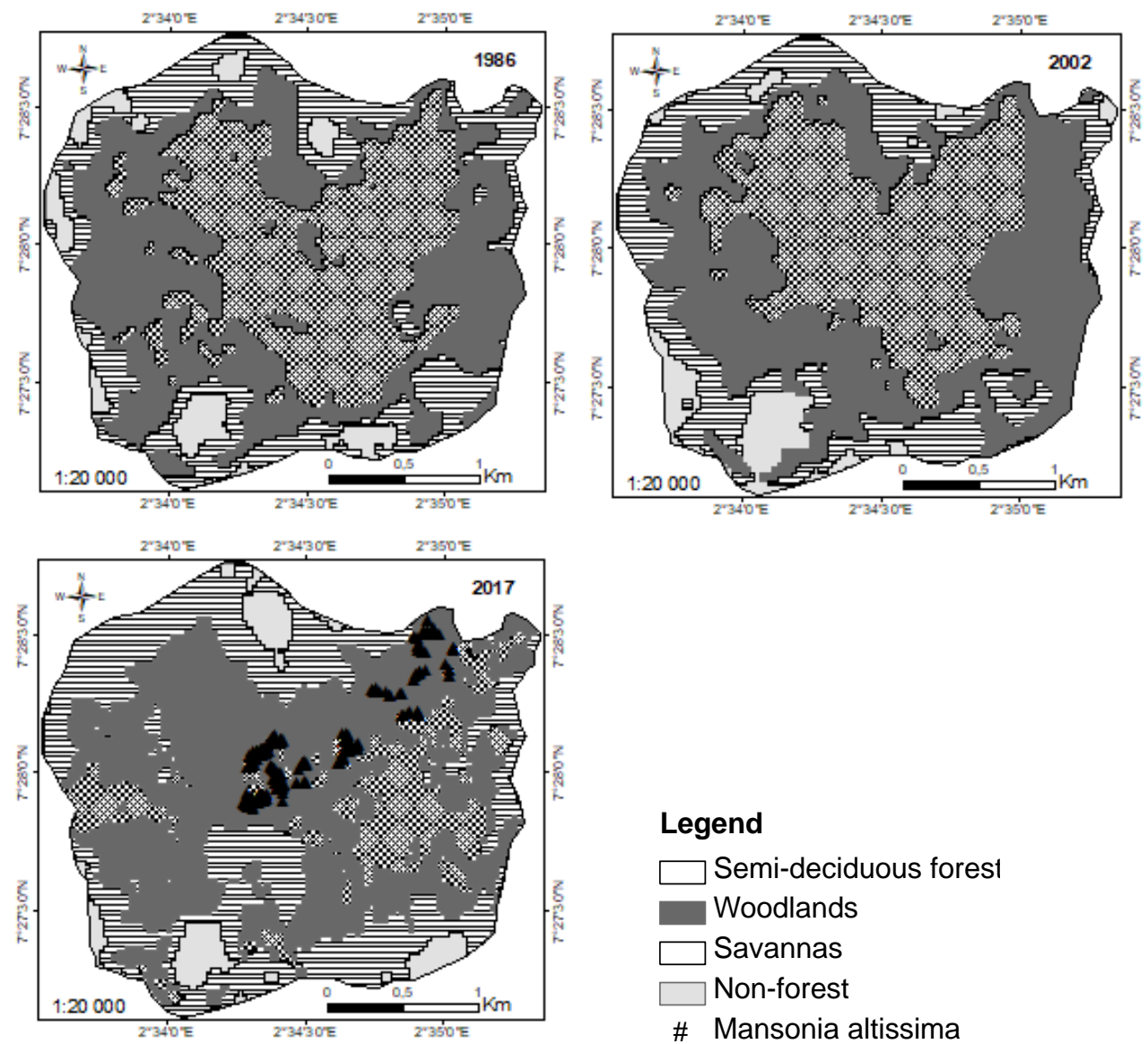

\section{Legend}

$\square$ Semi-deciduous fores 1

Woodlands

$\square$ Savannas

$\square$ Non-forest

\# Mansonia altissima 
Wédjangnon et.al: Assessing the landscape pattern and population status of the timber species Mansonia altissima A. Chev. for restoration purposes in moist semi-deciduous forest.

Fig. 4: Spatial and temporal distribution of changes in the three forest categories from the sacred groves of Adakplamè. SDF = semi-deciduous forest
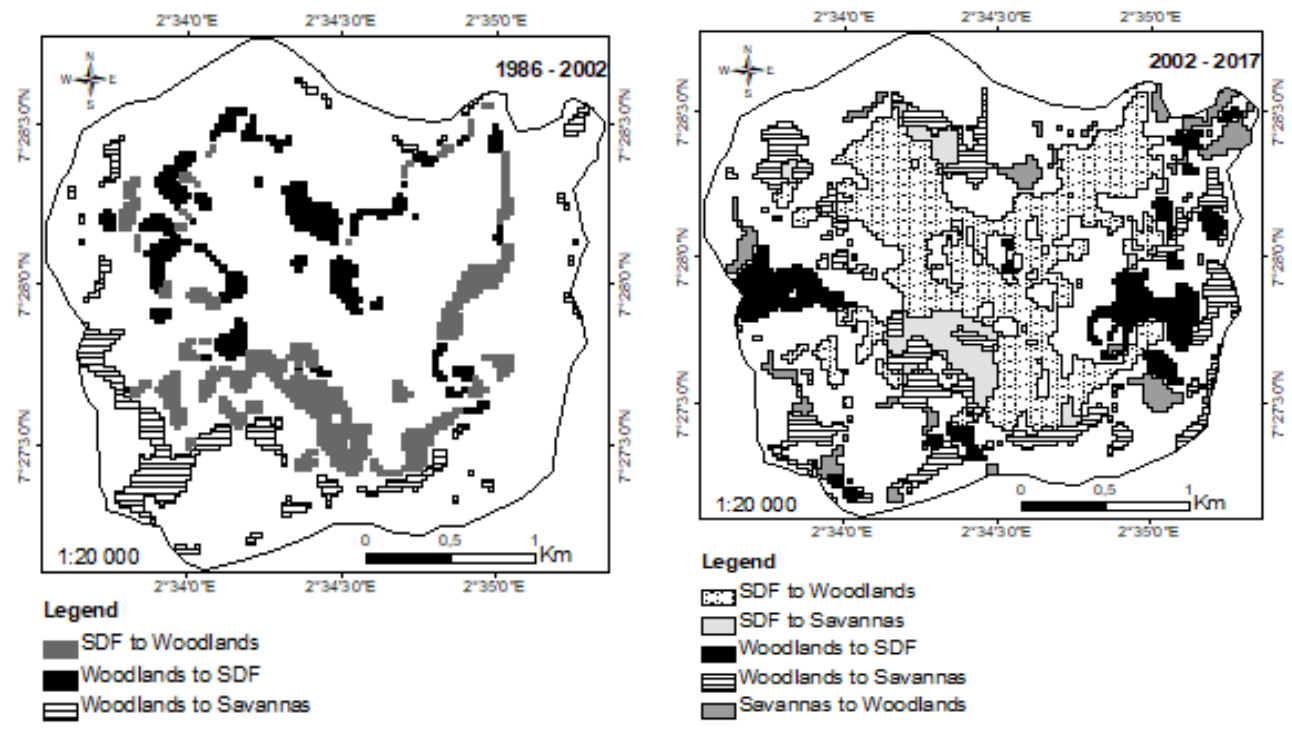

\section{Landscape spatial pattern in the sacred groves of Adakplamè}

The number of patches (NP) in the forest generally increased between 1986 and 2017 although there was a decrease between 1986 and 2002 (Table 3). The greatest reduction in mean patch size (MPS) and the greatest increase in the number of patches occurred between 2002 and 2017, which revealed that the forest had undergone severe landscape fragmentation during this period. The lowest number of patches was observed for SDF in $2002(\mathrm{NP}=6)$, likewise the largest number of patches was observed in the same category in $2017(\mathrm{NP}=32)$, which revealed that SDF had undergone more severe fragmentation between 2002 and 2017. The largest patch index (LPI) in SDF decreased from $23.1 \%$ to $5.3 \%$, whereas it increased in the other forest categories. These results also revealed that SDF was dramatically fragmented. In this category normalized landscape shape index (nLSI) decreased from 0.06 in 1986 to 0.04 in 2002, and aggregation index (AI) increased from $94.4 \%$ in 1986 to $96.3 \%$ in 2002. After 2002, nLSI strongly increased (nLSI $=0.18$ ), whereas AI decreased from $96.3 \%$ to $82.3 \%$. These indices revealed that SDF category, more aggregated between 1986 and 2002, became increasingly disaggregated. Thus, both fragmentation and disaggregation in SDF became more severe after 2002. Likewise, nLSI and AI showed similar trends in woodlands and non-forest, but with smaller values, whereas savannas became increasingly aggregated.

The mean nearest-neighbor distance (ENN_Mean) generally decreased between 1986 and 2017 except SDF category where ENN-Mean increased from 79 m in 1986 to $114 \mathrm{~m}$ in 2002. The ENN coefficient of variation (CV) increased in each category between 1986 and 2017, which revealed an irregular distribution of patches mainly in SDF and woodlands where the coefficient of variation was the highest in 2017. In SDF category, the ENN_Mean decreased from $114 \mathrm{~m}$ in 2002 to $85 \mathrm{~m}$ in 2017, whereas the coefficient of variation increased from $0.21 \mathrm{in}$ 2002 to 0.31 in 2017, which corroborated patch isolation and increase. These results revealed that there was strong increase of anthropogenic disturbance during the period 2002 to 2017, which drove the close forests to open forests. The patch size coefficient of variation was high in 
each landscape category from 1986 to 2017, which revealed the presence in each category patches with larger size and patches with smaller size than the average. This larger variability in patch size was also confirmed like an increase in patch shape complexity (PAFRAC > 1) in each category, which also revealed strong increase of anthropogenic disturbance.

Table 3: Landscape spatial pattern indices in the sacred groves of Adakplamè

\begin{tabular}{lccccccccc}
\hline $\begin{array}{l}\text { Landscape } \\
\text { category }\end{array}$ & NP & LPI (\%) & nLSI & MPS (ha) & CV & PAFRAC & AI (\%) & \multicolumn{2}{c}{ ENN (m) } \\
Mean & CV \\
\hline SDF & 10 & 23.1 & 0.06 & 24.4 & 281.9 & 1.3 & 94.4 & 79 & 0.19 \\
SDF & 6 & 22.9 & 0.04 & 38.6 & 220.4 & N/A & 96.3 & 114 & 0.21 \\
SDF & 32 & 5.3 & 0.18 & 3.4 & 282.4 & 1.3 & 82.3 & 85 & 0.31 \\
Woodlands & 14 & 27.1 & 0.1 & 24.3 & 284.4 & 1.4 & 89.9 & 169 & 0.2 \\
Woodlands & 7 & 34.0 & 0.08 & 49.7 & 238.6 & N/A & 92.3 & 121 & 0.2 \\
Woodlands & 18 & 33.2 & 0.1 & 21.4 & 352.1 & 1.4 & 90.2 & 84 & 0.33 \\
Savannas & 12 & 12.7 & 0.13 & 25.2 & 178.9 & 1.5 & 87.8 & 111 & 0.2 \\
Savannas & 13 & 18.8 & 0.11 & 20.4 & 248.2 & 1.4 & 89.3 & 110 & 0.19 \\
Savannas & 17 & 17.7 & 0.1 & 22.1 & 242.4 & 1.4 & 90.1 & 112 & 0.26 \\
Non-forest & 18 & 2.1 & 0.12 & 6.3 & 91.8 & 1.2 & 86.8 & 220 & 0.08 \\
Non-forest & 13 & 8.6 & 0.09 & 11.9 & 190.8 & 1.3 & 90.8 & 197 & 0.1 \\
Non-forest & 21 & 4.6 & 0.16 & 6.2 & 173.3 & 1.2 & 88.5 & 155 & 0.19 \\
\hline
\end{tabular}

From top to bottom the results per landscape category in 1986, 2002 and 2017

\section{Population status of $M$. altissima in the sacred groves of Adakplamè}

Table 4 shows demographic parameters (abundance, diameter increment, recruitment and mortality) of the population according to the life stages. Mortality rate was $6.79 \%$ year $^{-1}$ in the population. Between initial (February 2017) and last (February 2019) censuses, abundance in sampled plots decreased from 625 to 599 plants. Similarly, recruitment and mortality rates were respectively $3.14 \%$ year $^{-1}$ and $3.92 \%$ year $^{-1}$ at the seedling stage, $2.19 \%$ year $^{-1}$ and $1.05 \%$ year $^{-1}$ at the sapling stage. Both seedling and sapling stages displayed a net change of $-0.78 \%$ and $1.14 \%$ in abundance respectively. Mortality rates at premature and mature stages were $1.29 \%$ year $^{-1}$ and $0.40 \%$ year $^{-1}$ respectively. Thus, abundance decreased in all the life stages except sapling stage where abundance between initial and last censuses increased from $34.08 \%$ to $37.90 \%$ of the population.

Table 4: Demographic parameters according to the life stages of $M$. altissima

\begin{tabular}{lcclll}
\hline Life stages & $\mathrm{N}_{0}$ & $\mathrm{~N}_{\mathrm{t}}$ & Dincr & Recruitment & Mortality \\
\hline Seedling & 19.04 & 16.69 & $0.80 \pm 0.19$ & 3.14 & 3.92 \\
Sapling & 34.08 & 37.90 & $0.81 \pm 0.24$ & 2.19 & 1.05 \\
Premature & 31.84 & 30.55 & $0.68 \pm 0.23$ & & 1.29 \\
Mature & 15.04 & 14.86 & $0.50 \pm 0.23$ & & 0.40 \\
P-value (Kruskal-Wallis' test) & & $<0.000$ & & \\
\hline
\end{tabular}

$\mathrm{N}_{0}=$ abundance at initial census $\left(\%\right.$ year $\left.^{-1}\right) ; \mathrm{N}_{\mathrm{t}}=$ abundance at last census $\left(\%\right.$ year $\left.^{-1}\right)$; Dincr $=$ diameter increment $\left(\mathrm{cm}\right.$ year $\left.{ }^{-1}\right)$.

Diameter increment rate after the three censuses was $0.71 \mathrm{~cm} \mathrm{year}^{-1}$ in the population. Diameter increment is larger at early growth. Negative correlation was displayed between diameter increment and initial DBH $(r=-0.37, \mathrm{p}<0.000)$. Seedlings and saplings showed diameter increment rates of $0.80 \pm 0.19 \mathrm{~cm}_{\text {year }}{ }^{-1}$ and $0.81 \pm 0.24 \mathrm{~cm} \mathrm{year}^{-1}$ respectively. After both seedling and sapling stages, diameter increment rate decreased from $0.68 \pm 0.23 \mathrm{~cm}$ 

A. Chev. for restoration purposes in moist semi-deciduous forest.

year $^{-1}$ to $0.50 \pm 0.23 \mathrm{~cm}_{\text {year }}{ }^{-1}$ in both premature and mature stages respectively. Diameter increment rates among life stages differed significantly $(\mathrm{p}<0.000$; Table 4), but disturbance levels did not $\left(\mathrm{p}=0.14\right.$; Table 5). Diameter increment rates were $0.71 \pm 0.27 \mathrm{~cm} \mathrm{year}^{-1}$ (poor disturbance), $0.76 \pm 0.25 \mathrm{~cm}$ year $^{-1}$ (moderate disturbance) and $0.69 \pm 0.23 \mathrm{~cm}$ year ${ }^{-1}$ (strong disturbance).

Table 5: Demographic parameters of $M$. altissima according to the disturbance levels in the forest

\begin{tabular}{|c|c|c|c|c|c|}
\hline Disturbance levels & $\mathrm{N}_{0}$ & $\mathrm{~N}_{\mathrm{t}}$ & Dincr & Recruitment & Mortality \\
\hline Poor & 41.76 & 45.74 & $0.71 \pm 0.27$ & 2.54 & 0.48 \\
\hline Moderate & 14.08 & 13.02 & $0.76 \pm 0.25$ & 0.42 & 0.80 \\
\hline Strong & 44.16 & 40.23 & $0.69 \pm 0.23$ & 2.37 & 5.43 \\
\hline P-value (Kruskal-Wllis' test) & & & 0.14 & & \\
\hline
\end{tabular}

Mortality rate was higher at strong disturbance level $5.43 \%$ year $^{-1}$ (Table 5). At moderate and poor disturbance levels, mortality rates were $0.80 \%$ year $^{-1}$ and $0.48 \%$ year $^{-1}$ respectively. By contrast, recruitment rate was higher at poor disturbance level $2.54 \%$ year $^{-1}$. Thus, disturbance levels increased mortality rates of $M$. altissima (Table 6). However, recruitment among disturbance levels did not differ significantly (Table 7). Mortality decreased significantly when diameter size increased (sapling $\mathrm{z}=-6.40, \mathrm{p}<0.000$; premature $\mathrm{z}=-4.73, \mathrm{p}<0.000$; mature $\mathrm{z}=-5.36, \mathrm{p}<0.000)$, but increased significantly when disturbance levels increased (moderate $\mathrm{z}=3.75, \mathrm{p}<0.00$; strong $\mathrm{z}=6.59, \mathrm{p}<0.000$ Table 6). Mortality and recruitment of $M$. altissima among interaction life stages and disturbance levels did not differ significantly.

Table 6: Plant mortality according to the life stages of $M$. altissima and disturbance levels in the forest

\begin{tabular}{lllll}
\hline & Estimate & Std. Error & $\mathrm{Z}$ value & $\operatorname{Pr}>\mathrm{z}$ \\
\hline (Intercept) & -1.44 & 0.20 & -7.25 & $4.12 \mathrm{e}-13$ \\
Sapling & -1.19 & 0.19 & -6.40 & $1.54 \mathrm{e}-10$ \\
Premature & -0.87 & 0.18 & -4.73 & $2.23 \mathrm{e}-06$ \\
Mature & -1.37 & 0.26 & -5.36 & $8.10 \mathrm{e}-08$ \\
Moderate & 1.00 & 0.27 & 3.75 & 0.000176 \\
Strong & 1.39 & 0.21 & 6.59 & $4.37 \mathrm{e}-11$ \\
\hline
\end{tabular}

Table 7: Plant recruitment according to the life stages of $M$. altissima and disturbance levels in the forest

\begin{tabular}{lllll}
\hline & Estimate & Std. Error & $\mathrm{Z}$ value & $\mathrm{Pr}>\mathrm{z}$ \\
\hline (Intercept) & -0.53 & 0.15 & -3.66 & 0.000256 \\
Sapling & -0.57 & 0.16 & -3.67 & 0.000242 \\
Moderate & -0.40 & 0.28 & -1.41 & $0.16(\mathrm{~ns})$ \\
Strong & -0.19 & 0.16 & -1.19 & $0.23(\mathrm{~ns})$ \\
\hline
\end{tabular}

ns: not significant probability 
The fruiting rate computed for $M$. altissima between the three censuses showed that $25.37 \%$ of premature plants $(10 \leq \mathrm{DBH}<20 \mathrm{~cm})$ and $88.35 \%$ of mature plants $(\mathrm{DBH} \geq 20$ $\mathrm{cm})$ had fruited at least once. The minimum fruiting diameter recorded was $14.5 \mathrm{~cm}$.

\section{DISCUSSION}

\section{Change and spatial pattern of the landscape in the sacred groves of Adakplamè}

The changes observed in the forest can be characterized by two fundamental concepts of forest dynamics: deforestation and forest degradation. Deforestation is the result of a land cover dynamic in that forest categories are replaced by other land cover types such as agricultural spaces and savannas, while forest degradation is a process of change in the forest that negatively affects the landscape pattern and its composition (Bamba, 2010; Simula, 2009). The latter concerns more the attribute and running of the forest and generally followed by plant cover reduction, in particular the trees (Simula, 2009). Thus, transition from semi-deciduous forest (SDF) to forest woodland describes SDF degradation.

The transition matrix analysis revealed an increase of extent for woodlands and savannas between 1986 and 2017 and a decrease of semi-deciduous forest. The SDF, natural habitat of $M$. altissima, underwent dramatically reduction which revealed a weak protection of the forest. This landscape category was more fragmented with patches increasingly isolated and large variability in patch size. The sacred groves of Adakplamè, formerly dense forest declined to forest woodlands and savannas indicated by increase of their extent and the largest patch index (LPI). Based on the analyses of the transition matrix and landscape pattern metrics, we understood that anthropogenic disturbance in the forest increased severely between 2002 and 2017. The main factors of fragmentation and change of the close forests to open forests were fire, harvesting of wood for fuel and logging (Figure 5). Dramatically increase of anthropogenic disturbance could be explained by the conflict of forest ownership between the local populations since the adoption of the forest management plan which unfortunately could not be implemented due to the conflict. Although non-forest category gained highly did not replace SDF category during the study period. This change dynamic revealed that residential and agricultural overlaps were not the main processes of changes in SDF. However, their adjacency and non-conservative practices such as fire, wood logging and harvesting of non-timber forest products by the local population were main threat factors identified. The anthropogenic disturbance in the landscape despite its status of sacred groves could also be a consequence of animist beliefs disappearance by a few years because of the monotheistic or extraneous religions. Currently with the emergence of other religions, the weakness of traditional authorities and beliefs, prohibitions have broken, which led the majority of the sacred groves to the decline and emblematic species are prone to disappearance (Alohou et al., 2016). The forest degradation in the closest forest islands must worry conservationists who should exert efforts for the conservation of these particular forest ecosystems in order to attenuate the century's challenge that is climate change.

\section{Implications of anthropogenic disturbance in the population status of $M$. altissima}

In Benin, the small remaining population of $M$. altissima is affected by habitat degradation caused by fire, human-caused damage to seedlings, and agriculture. Mortality was higher in plots disturbed strongly while recruitment of seedlings and samplings was higher in plots poor disturbed, but diameter increment did not vary with anthropogenic disturbance levels. Recruitment in plant population ecology refers to the presence of new plant individuals within existing population (Eriksson \& Ehrlén, 2015) or the transition of plant individuals beyond a certain size threshold (Lexerød \& Eid, 2005; Favrichon et al., 1998; Helms, 1998). 
However, several recruitment studies in plant communities only consider seedlings because they are usually small and subject to various abiotic and biotic factors causing higher mortality rates (Eriksson \& Ehrlén, 2015). Nevertheless, seedling recruitment is assessed arbitrarily in population studies due to the difficulties to define a size limit for seedlings of any plant species (Kitajima \& Fenner 2000; Favrichon et al., 1998). In this study, we used abundance of seedlings and saplings to assess the recruitment of $M$. altissima and we found that recruitment was lowest in seedlings due to their highest mortality rate. Disturbance levels did not significantly affect recruitment, but did significantly affect mortality rate. Anthropogenic disturbance by fire and agricultural practices about the forest significantly increased seedlings mortality rate and contributed to the continuous population decline. This result showed that natural regeneration contributed by samplings was greater in disturbed population of $M$. altissima and will create long-term imbalance within the population. Fire not only devastate seedlings and mature plants (Figure 5.e,f) but also facilitates establishment of invasive weeds like Chromolaena odorata (L.) that inhibit seedling establishment and survival. The presence of dead plants of M. altissima in agricultural spaces (Figure 5.g) is an indicator of agricultural overlaps inside the forest.

Fig. 5: Effects of anthropogenic disturbance in the forest landscape at Adakplamè, (a) residential, (b) agricultural overlap, (c, d) harvesting of firewood and establishment of invasive weeds after fire, $(e, f, g)$ effects of fire and agricultural overlaps on M. altissima
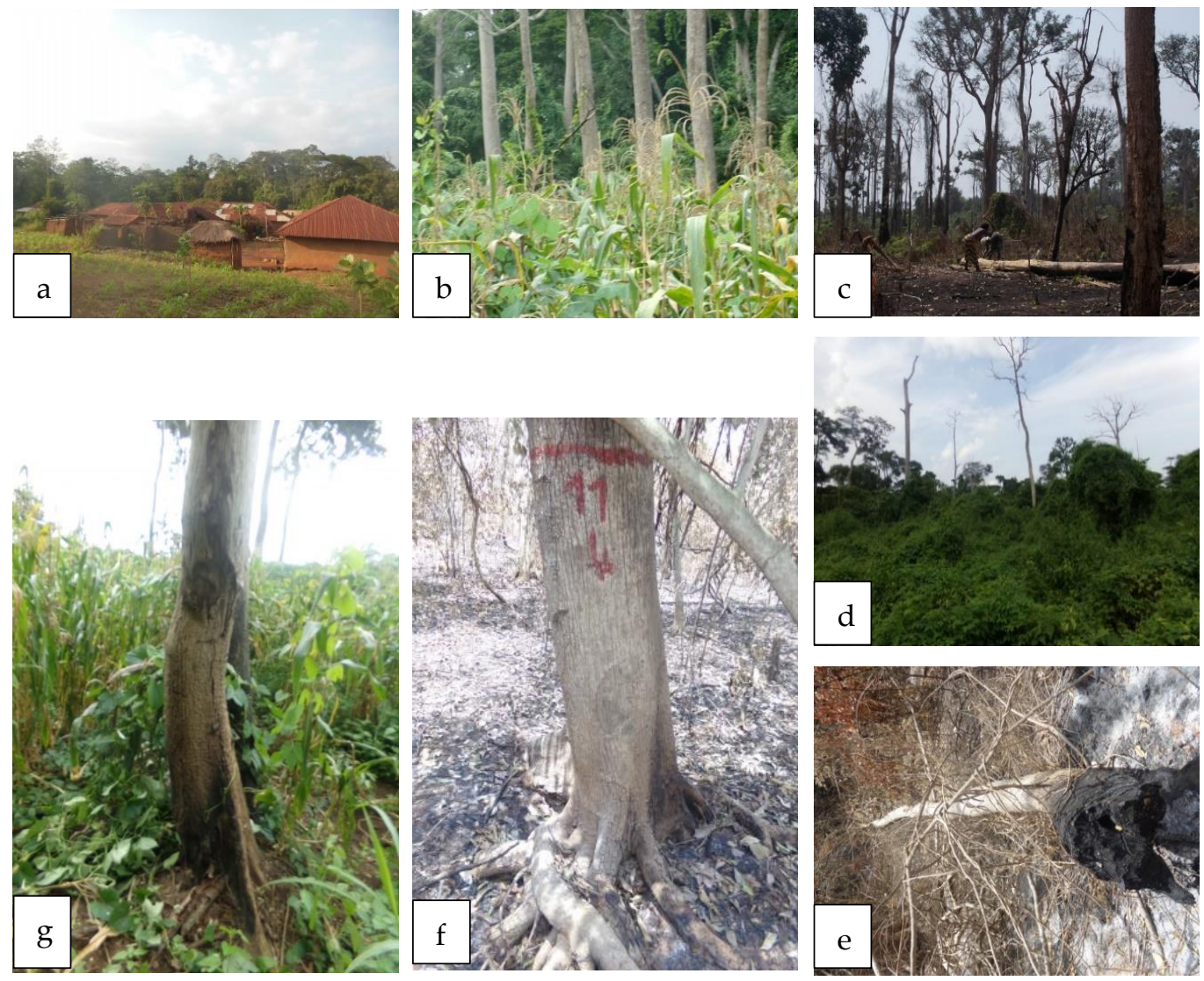
Apart from anthropogenic disturbance, young seedlings (plants with diameter $<1 \mathrm{~cm}$ ) were also affected by water deficiency during the dry season due to the period of germination. Young seedlings appear between July and August, but a prolonged drought during five months from November to March could create them hard live conditions increasing the mortality rates in plants with diameter $<1 \mathrm{~cm}$. Anthropogenic disturbance associated with strong drought during data collection period could also explained the reduced proportion of the seedlings.

The landscape fragmentation and forest cover reduction affect the population viability because of changes in seed germination and seedling establishment conditions (Uriarte et al., 2010). They also contribute to the decline in pollinator's population, which could reduce seed production (Gómez et al., 2010; Aguilar et al., 2006), while literature reported that $M$. altissima seems to be pollinated by insects despite lack of appropriate study on the pollination biology in the species (Akinnagbe et al., 2019). They negatively affect genetic diversity of non-pioneer tree species occurring in closed forests (Akinnagbe et al., 2019). If some plant species like Ceiba pentandra (L.) Gaertn and Triplochiton scleroxylon K. Schum. found in the same habitat maintain their genetic diversity even in changing landscape because of their ability to colonize open landscapes, $M$. altissima to the contrary shows lower genetic diversity in disturbed landscapes and its regeneration is very poor in open landscapes (Akinnagbe et al., 2019). This suggests that the population of M. altissima in Benin could subject to genetic erosion, which could pose a serious threat for their future viability. The lowest abundance in each life stage would be insufficient to maintain permanent this population of $M$. altissima in view of its lower genetic diversity in disturbed landscapes.

\section{Management strategy of the population and its native habitat}

Forest degradation and fragmentation in habitats can have severe consequences for biodiversity conservation, including local extinctions of native species dependent to some particular forest habitats. This situation raises a critical question for management of rare species occurring as small and isolated population in a highly anthropized landscape. While access to the communal forests cannot be avoided due to their medicinal, food, economic and social roles, they should be protected from forest destruction to avoid rare species extinctions, which are important for local populations. Conservation strategies of the forest should seek to manage peacefully the conflict of forest ownership and observed impacts, including reforestation of degraded area using threatened native species in the forest like M. altissima and other species having similar demography in the forest and listed in Benin's red list (Neuenschwander et al., 2011) rather than exotic species, in order to restore the ecological functions of this forest. It is also needed to reinforce the traditional management system to restrict public access to the forest.

\section{CONCLUSIONS}

Forest degradation in the natural habitat of Mansonia altissima in Benin, caused by anthropogenic disturbance factors, such as, fire, damage of human activities on seedlings, harvesting of wood for fuel, and agriculture extent increased population mortality of the species. The population of $M$. altissima had no germination problem, but the lack of population recruitment was caused by the highest mortality in seedlings and semi-deciduous forest decline. Since the population cannot be completely protected due to the status of sacred groves and the fact that the habitat is surrounded by agricultural and residential spaces, we strongly suggest translocation of the species for its conservation in protected forests within their potential niche. Translocation of M. altissima will enable to increase the survival chance 
of the species. Experimental restoration in protected forests outside distribution range of the species is required in order to identify locations where the species can establish young viable populations for an efficient management of M. altissima in Benin. Additionally, fire and other anthropogenic disturbance in the forest must be controlled to ensure this natural population can provide seeds for restoration and conservation projects. Impacts of anthropogenic disturbance factors (forest degradation, fragmentation and destruction) combined with ongoing and future climate change indicate that experimental restoration is not only required for $M$. altissima, but also other tree species with similar population dynamics and growing in weak protected forest habitats in West Africa.

\section{FUNDING}

This research did not receive any specific grant from funding agencies in the public, commercial, or not-for-profit sectors.

\section{ACKNOWLEDGMENTS}

The authors are grateful to King of Adakplamè who allowed us to carry out this research in these sacred groves containing some deities. We are also grateful to the anonymous reviewers for the useful comments which contributed to improve the quality of the paper.

\section{REFERENCES}

African Regional Workshop (1998). Conservation \& Sustainable Management of Trees, Zimbabwe, July 1996. Mansonia altissima var altissima The IUCN Red List of Threatened Species: e.T32283A9686553. Retrieved June 8, 2019, from doi: 10.2305/IUCN.UK.1998. RLTS.T32283A9686553.en.

Aguilar, R., Ashworth, L., Galetto, L. \& Aizen, M.A. (2006). Plant reproductive susceptibility to habitat fragmentation: review and synthesis through a meta-analysis. Ecol. Lett. 9, 968-980. doi:10.1111/j.1461-0248.2006.00927.x

Akinnagbe, A., Gailing, O., Finkeldey, R. \& Lawal, A. (2019). Towards conservation of genetic variation of tropical tree species with differing successional status: The case of Mansonia altissima A. Chev and Triplochiton scleroxylon K. Schum. Trop. Conserv. Sci. 12, 1-9. doi: 10.1177/1940082919864267

Aldwaik, S. \& Pontius, R.Jr. (2012). Intensity analysis to unify measurements of size and stationarity of land changes by interval, category, and transition. Landscape Urban Plan, 106, 103-114. Doi: 10.1016/j.landurbplan.2012.02.010

Alohou, E.C., Gbemavo, D.S.J.C., Ouinsavi, C. \& Sokpon, N. (2016). Local perceptions and importance of endogenous beliefs on sacred groves conservation in South Benin. Int J Biodivers Conserv, 5, 105-112. doi: 10.5897/IJBC2015.0918

Ashton, M.S., Hooper, E.R., Singhakumara, B. \& Ediriweera, S. (2018). Regeneration recruitment and survival in an Asian tropical rain forest: implications for sustainable management. Ecosphere, 9, e02098. doi: 10.1002/ecs2.2098 
Bamba, I. (2010). Anthropisation et dynamique spatio-temporelle de paysages forestiers en République Démocratique du Congo. PhD thesis, Université Libre de Bruxelles, Belgique. p 205.

Botanic Gardens Conservation International (BGCI) \& IUCN SSC Global Tree Specialist Group (2018) Mansonia altissima. The IUCN Red List of Threatened Species: e.T62753A136113496. Retrieved June 8, 2019, from doi:10.2305/IUCN.UK.20182.RLTS.T62753A136113496.en.

Buma, B. (2011). Evaluating the utility and seasonality of NDVI values for assessing post-disturbance recovery in a subalpine forest. Environ Monit Assess. doi: 10.1007/s10661-011-2228-y

Cabello, J., Fernàndez, N., Alcaraz-Segura, D., Oyonarte, C., Piñeiro, G., Altesor, A., Delibes, M. \& Paruelo, J.M. (2012). The ecosystem functioning dimension in conservation: insights from remote sensing. Biodivers. Conserv. 21, 3287-3305. doi: 10.1007/s10531-012-0370-7

Cordell, S., Questad, E.J., Asner, G.P., Kinney, K.M., Thaxton, J.M., Uowolo, A., Brooks, S. \& Chynoweth, M.W. (2018). Remote sensing for restoration planning: how the big picture can inform stakeholders. Restor. Ecol. 25, S147-S154. doi: 10.1111/rec.12448

De Madron, L.D. (2003). Accroissement diamétrique du bété et de l'iroko. Bois For. Trop. 275, 83-87.

Dionisio, L.F.S., Schwartz, G., Lopes, J. do C. \& Oliveira, F. de A. (2018). Growth, mortality, and recruitment of tree species in an Amazonian rainforest over 13 years of reduced impact logging. For. Ecol. Manag. 430, 150-156. https://doi.org/10.1016/ j.foreco.2018.08.024

Ellstrand, N.C., Elam, D.R. (1993). Population genetic consequences of small population size: implications for plant conservation. Annu. Rev. Ecol. Evol. Syst. 24, 217-242

Eriksson, O. \& Ehrlén, J. (2015). Seedling recruitment and population ecology. In Leck, M.A., Thomas Parker, V., Simpson, R.L. (Eds). Seedling Ecology and Evolution (pp. 239-254). Cambridge: Cambridge University Press. doi: 10.1017/CBO9780511815133.013

Favrichon, V., Gourlet-Fleury, S., Bar-Hen, A. \& Dessard, H. (1998). Parcelle permanente de recherché en forêt dense tropicale humide. Eléments pour une méthodologie d'analyse de données. CIRAD-Forêt, Série FORAFRI, Document 14, p.73

Gross, A., da Silva, A.C., Cruz, A.P., Kilca, R. de V., da Silva Nunes, A., Duarte, E., Vefago, M.B., dos Santos, G.N., Lima, C.L., Salami, B. \& Higuchi, P. (2018). Fragmentation as a key driver of tree community dynamics in mixed subtropical evergreen forests in Southern Brazil. For. Ecol. Manag. 411, 20-26. https://doi.org/10.1016/j.foreco.2018.01.013

Gómez, J.M., Abdelaziz, M., Lorite, J., Muñoz-Pajares, A.J. \& Perfectti, F. (2010). Changes in pollinator fauna cause spatial variation in pollen limitation. J. Ecol. 98, 1243-1252. doi: 10.1111/j.1365-2745.2010.01691.x

Helms, J.A. (1998). The dictionary of forestry. The Society of American Foresters, 210 p.

Kitajima, K. \& Fenner, M. (2000). Seedling regeneration ecology. 2nd edn (ed. M. Fenner). Seeds: Ecology of Regeneration in Plant Communities. CAB International, Wallingford, UK. 331-360.

Klank, C., Pluess, A.R. \& Ghazoul, J. (2010). Effects of population size on plant reproduction and pollinator abundance in a specialized pollination system. J. Ecol. 98, 13891397. doi: 10.1111/j.1365-2745.2010.01720.x 
Wédjangnon et.al: Assessing the landscape pattern and population status of the timber species Mansonia altissima A. Chev. for restoration purposes in moist semi-deciduous forest.

Klopčič, M., Simončič, T. \& Bončina, A. (2015). Comparison of regeneration and recruitment of shade-tolerant and light-demanding tree species in mixed uneven-aged forests: experiences from the Dinaric region. Forestry 88, 552-563. doi:10.1093/forestry/cpv021

Laurance, W.F., Goosem, M. \& Laurance, S.G.W. (2009). Impacts of roads and linear clearings on tropical forests. Trends Ecol. Evol. 24, 659-669. https://doi.org/10.1016/ j.tree.2009.06.009

Lexerød, N. \& Eid, T. (2005). Recruitment models for Norway spruce, scots pine, birch and other broadleaves in young growth forests in Norway. Silva Fenn. 39, 391-406. https://doi.org/10.14214/sf.376

McGarigal, K., Cushman, S.A. \& Ene, E. (2012). FRAGSTATS v4.2: Spatial Pattern Analysis Program for categorical and Continuous Maps. Computer software program produced by the authors at the University of Massachusetts, Amherst. Retrieved June 8, 2019, from http://www.umass.edu/landeco/research/fragstats/fragstats.html

Mendoza, E., Fay, J. \& Dirzo, R. (2005). A quantitative analysis of forest fragmentation in Los Tuxtlas, southeast Mexico: patterns and implications for conservation. Rev. Chil. Hist. Nat. 78, 451-467. http://dx.doi.org/10.4067/S0716-078X2005000300008

Mensah, S., Houehanou, T.D., Sogbohossou, E.A., Assogbadjo, A.E. \& Glèlè Kakaï, R. (2014). Effect of human disturbance and climatic variability on the population structure of Afzelia africana Sm. ex pers. (Fabaceae-Caesalpinioideae) at country broad-scale (Bénin, West Africa). S. Afr. J. Bot. 95, 165-173. http://dx.doi.org/10.1016/j.sajb.2014.09.008

Neuenschwander, P., Sinsin, B. \& Goergen, G. (2011). Protection de la Nature en Afrique de l'Ouest: Une Liste Rouge pour le Bénin. Nature Conservation in West Africa: Red List for Benin. International Institute of Tropical Agriculture, Ibadan, Nigeria, p. 365.

Ouédraogo, D.Y., Doucet, J.L., Daïnou, K., Baya, F., Biwolé, A.B., Bourland, N., Fétéké, F., Gillet, J.F., Kouadio, Y.L. \& Fayolle, A. (2018). The size at reproduction of canopy tree species in central Africa. Biotropica 50, 465-476. doi:10.1111/btp.12531

Pereira, H.M. \& Cooper, H.D. (2006). Towards the global monitoring of biodiversity change. Trends Ecol. Evol. 21, 123-129. doi: 10.1016/j.tree.2005.10.015

PIFSAP [Projet d'Intégration des Forêts Sacrées dans les Aires Protégées]. (2012). Plan d'aménagement et de gestion simplifié de la forêt sacrée de Kouvizoun, $\mathrm{N}^{\circ} 00076343$, DGFRN, MEHU, République du Bénin. p.50

Puyravaud, J-P. (2003). Standardizing the calculation of the annual rate of deforestation. For. Ecol. Manag. 177, 593-596.

Questad, E.J., Kellner, J.R., Kinney, K., Cordell. C., Asner, G.P., Thaxton, J., Diep, J., Uowolo, A., Brooks, S., Inman-Narahari, N., Evans, S.A. \& Tucker, B. (2014). Mapping habitat suitability for at-risk plant species and its implications for restoration and reintroduction. Ecol. Appl. 24, 385-395.

$\mathrm{R}$ Core Team. (2018). $R$ : A language and environment for statistical computing. $\mathrm{R}$ Foundation for Statistical Computing, Vienna, Austria. Retrieved June 8, 2019, from https://www.R-project.org/

Reis, B.P., Martins, S.V., Filho, E.I.F., Sarcinelli, T.S., Gleriani, J.M., Marcatti, G.E., Leite, H.G. \& Halassy, M. (2019). Management Recommendation Generation for Areas Under Forest Restoration Process through Images Obtained by UAV and LiDAR. Remote Sens. 11, 1508. doi: $10.3390 /$ rs 11131508 
Rodríguez-Echeverry, J. \& Leiton, M. (2019). Conservation planning in anthropogenic landscapes. Ecol. Conserv. Sci. 1, 555552.

Selwood, K.E., McGeoch, M.A. \& Nally, R.C. (2014). The effects of climate change and land-use change on demographic rates and population viability. Biol. Rev. 000-000. doi: $10.1111 /$ brv. 12136

Simula, M. (2009). Towards defining forest degradation: comparative analysis of existing definitions. Forest Resources Assessment, FAO, Rome, Itally, p. 154.

Tallmon, D.A., Jules, E.S., Radke, N.J. \& Mills, L.S. (2003). Of mice and mean and trillium: cascading effects of forest fragmentation. Ecol. Appl. 5, 1193-1203. https://doi.org/10.1890/02-5111

Tang, C.Q., He, L-Y., Gao, Z., Zhao, X-F., Sun, W-B. \& Ohsawa, M. (2011). Habitat fragmentation, degradation, and population status of endangered Michelia coriacea in Southeastern Yunnan, China. Mt. Res. Dev. 31, 343-350. doi.org/10.1659/MRD-JOURNAL-D-11-00004.1

Turner, W., Spector, S., Gardiner, N., Fladeland, M., Sterling, E. \& Steininger, M. (2003). Remote sensing for biodiversity science and conservation. Trends Ecol. Evol. 18, 306-314. doi: 10.1016/S0169-5347(03)00070-3

Uriarte, M., Bruna, E.M., Rubim, P., Anciães, M. \& Jonckheere, I. (2010). Effects of forest fragmentation on the seedling recruitment of a tropical herb: assessing seed vs. safe-site limitation. Ecology 5, 1317-1328.

Volis, S. (2018). Securing a future for China's plant biodiversity through an integrated conservation approach. Plant Divers. 40, 91-105

Volis, S., Dengo, T. (2019). Importance of a single population demographic census as a first step of threatened species conservation planning. Biodivers. Conserv. 29, 527-543

Wédjangnon, A.A., Houètchégnon, T. \& Ouinsavi, C. (2016). Caractéristiques ethnobotaniques et importance socio-culturelle de Mansonia altissima A. Chev. au Bénin, Afrique de l'Ouest. J. Anim. Plant Sci. 29, 4678-4690. 